\title{
Nexus between Child labor, Sector-specific Growth and International Trade in Pakistan
}

\author{
Sana Suleman \\ PhD Scholar, Department of Economics, University of Sargodha \\ sana_economist@yahoo.com \\ Maqbool H. Sial \\ Professor, School of Business and Economics \\ University of Management and Technology, Lahore \\ maqbool.hussain@umt.edu.pk \\ H. Nouman Siddique \\ MS Scholar, Department of Project Management \\ Bahria Business School, Bahria University, Islamabad \\ noumans8990@gmail.com
}

\begin{abstract}
This study focused on analyzing the impacts of different sectors' growth and globalization on child labor in Pakistan. The order of integration variables was found mix as some were I(0) and some were I(1). That's why, the long run and short run dynamics were evaluated through ARDL mechanism using data from 1980-2014. The long run and short run inferences revealed that growth reduced child labor significantly in all sectors except services. The urban population growth significantly lessened the child labor as compared to rural population. The FDI significantly decreased the child labor growth while trade openness did opposite. Results suggest that trade policy and labor laws of ILO should be implemented.
\end{abstract}

Key words: child labor, ARDL, FDI, ILO

\section{Introduction}

Now days at every economic platform from World Trade Organization to regional economic associations trade liberalization is hailed as an important corner stone in the roadmap of economic development. No doubt, every developed country of the world achieved progress when it liberalized its economy and opened it for other countries. Economic liberalization is also helping expansion of growth from one country to another and it is trying to remove bottlenecks (like excessive tariffs) which are an anathema for economic progress. On individual level economic liberalization is portrayed as savior of the masses because it promotes lower prices and extensive trade which help in raising the living standards of general public. There are some dark shades of economic liberalization 
too. It creates an exploitive environment in which technologically advanced countries snatch markets of less developed countries from domestic producers by introducing there high-quality commodities at low prices in developing countries. Many households face this fatal impact when their bread earners become unemployed in such mentioned situations.In recent times, economic liberalization is marching on a new path. Many Multinational companies (MNCs) are transferring their production units from developed countries to lesser developed countries where they can produce at low wages and soft regulations, thanks to liberal economic policies introduced by governments of these states to attract foreign investment. In developed countries there are strict regulations on treatment of labor including prohibition of child labor.

In least developed countries, albeit there are laws and regulations against child labor, there is no significant implementation of these laws. Beneath shining labels of Multinational companies the future of a nation is being exploited for petty profits. There is also an abhorrent trend in regions of the world plagued by internal or external disputes. In countries like Yemen, Burundi, Rwanda, Central African Republic and Congo in present and in Ethiopia, Angola, Serra Leone and Sudan in past children were being employed as soldiers on civil and international wars and same holds true for now (Finnstrom, 2008).

Religious societies are misusing the religion as an excuse for child labor, as terrorist organization like ISIS and Al- Quaida are using children as soldiers in Iraq and Syria (In the name of God and Islam). Same is the case in Pakistan where traditional agrarian societies exist in their own conservative clichés. Children are considered subordinates of their parents. In rural areas of Pakistan, it is common for children to work in fields with their parents even as wage laborers in time of sowing and harvesting of crops. Naturally there are fewer inhibitions against child labor in mind of a Pakistani citizen. Many farmers in Pakistan do not hire employees but they run their farms with the help of their children. Normally livestock kept by farmers is tended by their children who are hindered from going to school. There is also a preposterous mentality which stress that children of farmers do not need any education but their work which is done on farm is their real education. Female children are especially discouraged to get education, so many wage laborers working in fields sent their daughters to don chores in house of some landlord instead of sending them to school. They prefer small amount of earned money in that way rather to waste (in their opinion) on daughter's education that will get married and her education will not benefit household. (Hartjen and Priyadarsini, 2012). Due to large size of household, parents only cannot provide bread and butter for whole family. Parents prefer the children to work rather bring starved. That is why children also have to contribute to meet both ends. There are also some religious and traditional approaches which presume that a woman who is earning livelihood is a disgrace to her family. So, this burden has to borne by male children instead of getting education.

In addition to this, there are some traditional industries in Pakistan in which production is done intensively by children. Industrialists like football and carpet makers assert that 
tinder and delicate fingers of children are ideal for their required work. These footballs and carpets roam in world market as a mixed blessing of economic liberalization. There are shallow rants of banning the trade of these good produced by child laborers and even ban is imposed for some time. But it did not hinder theses industries to hire child laborers. The need of time is that international trade should not be based on profitability and risk. No doubt all economic activities are done for profit but the basic human rights must be given due respect. Trade in which child labor is employed should be discouraged. The same thing applies to parents which do not want to spend income on education of their children because they found it a risky venture due to common perception that sometimes educated person cannot earn money as much money they spent on education due to increasing unemployment. Parents find it profitable that there should be no expense on education and children could earn as much they can by doing petty jobs. Some industries are deliberately exploiting children by coercing them into to do labor for them. For example, brick making industry in Pakistan is run by wealthy creditors which force their debtors to work in their production units with their families. Children of these families also become a victim of this heinous practice. These elements should not be spared on basis of their role in trade and economy.

It is not only the case that trade liberalization affects child labor but the impact could be reversed. If child labor is not prevalent and young generation is getting education and learning skill from different institutions, they will take part in economic activities more efficiently which ultimately will benefit trade and economy. This should also be kept in mind that benefits of trade should be equally distributed to all population of that country otherwise benefits will be just numerical figures and overall society will be in poor same condition. For example, countries like India Gathia (1999), Indonesia and Hong Kong which have championed trade liberalization with their soft market friendly economic policies have serious issues of child labor because even these liberal policies did not change the attitude of societies and governments in these countries. Even in developed countries like Japan and South Korea child prostitution is causing a widespread concern. Child prostitution is most atrocious form of child labor. This problem exists on a much larger scale in emerging economies of Gulf (UAE, Qatar etc.) and Southeast Asia (like Thailand, Malaysia, Singapore).

According to Khalid and Shahnaz (2004) child labor in Pakistan is defined as work done by a person who is below the age of 14 years. A law passed in 1991 called Employment of Children Act it prohibits the hiring of any person under the age of 14 years. Harriet (2013) wrote in The Guardian that number of child laborers has been fallen from 215 million in 2000 to 167 million in 2013 according to International Labor Organization (ILO). But these numbers are not so promising because 167 million children engaged in child labor are not provided with basic rights of education and recreation. As for Pakistan, Hunt (2013) reported on CNN that Pakistan is ranked at sixth number amid ten worst countries in prevalence of child labor. 
By deciding the relation of trade liberalization and child labor, we can limit child labor resulting from increased globalization and greed for profit. If trade provides employment opportunities to parents, children do not have to worry about livelihood and concentrate on their education.

Previous studies only discussed the impact of trade openness and GDP percapita on the child labor like Sidiqqqui and Patrinos (1995), Khalid and Shahnaz (2004), Chaudry et al(2005) and Rehman et al (2013). The present study discussed the impact of different sector growth, population growth and trade openness on the child labor.

\section{Literature Reviews}

At macro level this issue addressed by a few of researchers but internationally a sound collection of empirical literature is present. Some of them are coated here.

Sidiqqqui and Patrinos (1995) examined Child labor that was especially prevalent in rural areas where the capacity to enforce minimum age requirements for schooling and work was deficient. Children work was common for variety of reasons, one of them was poverty. Schooling problems also add to child labor, whether it is the inaccessibility of schools or the lack of quality education which spurs parents to enter their children in more profitable pursuits.

Basu and Van (1998) described that how we define child work, how we define child, how we collect data but did not matter which estimates are used to measure the child labor. The aim of this study was to construct a model of child labor which can then be used to ask and answer some policy questions.

Brown et al (2002) analysed the specter of small children toiling long hours under dehumanizing conditions has precipitated an intense debate concerning child labor over the past decade and a half. Although child labor had been the norm throughout history, the fact of children working and the difficult conditions under which children work occasionally become more evident. Unitary models are analyze followed by models with multiple agency. We consider household decision - making, itself, along with market characteristics that constrain the choices that families make concerning their children.

Khalid and Shahnaz (2004) reported using child labor survey 1996 that there were 3.3 million children working between the ages of 5 and 14 years in Pakistan. This study examined the socio economic conditions of child labor in Pakistan and to highlight differences between households with working children and those households without any child workers. It also discusses the labor market conditions of child workers by using Labor Force Survey 1996-97.

Edmonds et al (2004) explored the relationship between exposure to trade and child labor in a cross country setting. The methodology accounts for the fact that trade flows were endogenous to child labor by examining the relationship between child labor and variation in trade based on geography. The study found that countries that had more trade had less child labor. Thus, the cross-country data did not substantiate assertions that trade per se plays a significant role in perpetuating the high levels of child labor that pervade low-income countries. 
Bandyopadhyay et al (2005) studied the existing literature on trade and child labor by exploring the effects of terms of trade changes in the context of a three good general equilibrium model, where one of the goods is a non-traded good. The study discovered that under quasi-linear preferences the effect of the terms of trade on child labor depends critically on the pattern of substitutability in the excess demand functions between the export good and the non-traded good. Chaudry et al(2005) analyzed that the implications of trade liberalization on the incidence of child labor in a two-sector general equilibrium framework. The study draw revealed that the effect of trade liberalization on the incidence of child labour crucially hinges on the relative factor intensities of the two sectors. Escobal et al (2007) analyzed the argument in favor of trade liberalization which positively affects the child labor. This study analyzed four dimensions in favour of trade liberalization which were useful for welfare of child. Study concluded that the effects of trade liberalization are difficult to trace and were mediated by regional and local characteristics, including differentiated transaction costs and market imperfections, that affect the impact of international prices on local prices.

Katos et al (2011) examined the effect of trade liberalization on child work in Indonesia. Our estimation strategy identifies geographical differences in the effects of trade policy through district level exposure to reduction in import tariff barriers. The study used balanced panel of 261 districts, based on four rounds of the Indonesian annual national household survey and relate workforce participation of children aged 10-15 to geographic variation in relative tariff exposure. The main findings showed that increased exposure to trade liberalization was associated with a decrease in child work among the 10 to 15 year olds. Nawaz et al(2011) examined how child labor effected by GDP percapita , income inequality and trade openness in Pakistan. The study found that in the short child labor dampens due to GDP/and in the long run it increases but inequality had positive connection with child labor. On the other hand, trade openness in both time period reduces the child labor.

Rehman et al (2013) analyzed the current trend of global child labour, and investigated the causes and consequences of child labour with a particular attention on globalisationchild labour nexus. Though a decreasing trend was observed, the incidence of child labour is still alarming. Though controversy exists, poverty is still a strong determinant of child labour. Among the other factors, parents' education, credit market constraints, schooling performance, child's nutrition and health status, family size and birth order, higher schooling costs, lack of quality education, employer's attitude, inappropriate government and mental health, educational outcomes, adult employment, adult earnings and bargaining power of adult workers contributed to child labor. The theoretical arguments regarding the effects of globalisation on child labour is ambiguous. Empirical evidences also provide us mixed results.

Vay et al (2014) examined how child labor rates within three broadly defined sectors and each sector export activities were considered. Study utilized newly available survey data which quantify sector level child activities. To the contrary, evidence suggests that higher 
sector exports are correlated with fewer children working within that sector, particularly in manufacturing.

\section{Data and Methodology}

The present study is a multivariate analysis that seeks for measuring the relationship between child labor with growth and international trade.Data and time constraint has confined the research to use following variables from the period 1981-2014. The variables are annually observed from WDI and ILO. Similar type of models were utilized in the studies ofEdmonds (2004) and Voy (2014) The child labor is dependent variable. The two models are formulated which are as under:

Table 3.1:Models

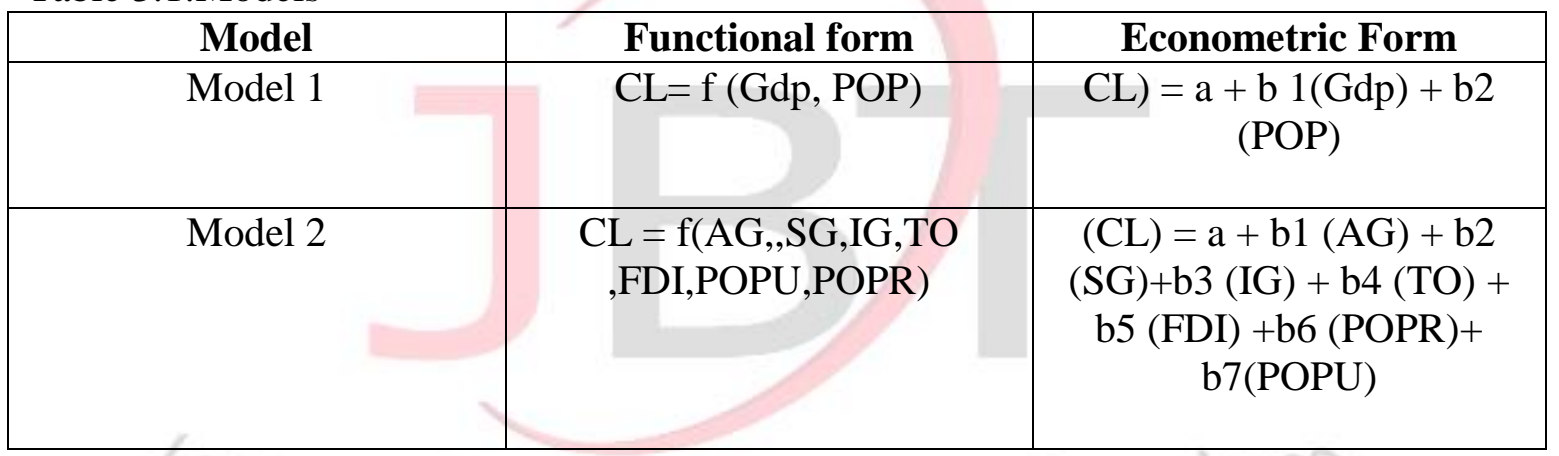

Where; CL: child labor (working children between the age of 10-14),AG: Agriculture growth rate,SG: services growth IG: Industrial growth rate,TO: trade openess = (import +export)/ngdp: nominal GDP,FDI: Foreign direct investment ,POP: Total Population, POPR: Rular Population growth and POPU: Urban Population growth

Present study focuses on the time series analysis. For any time, series analysis, the choice of estimation technique is purely an issue of stationarity. Results obtained by unit root test revealed that some of the variables are I(0) and some are I(1). So, ARDL was applied to estimate the mentioned models.

This approach is introduced by Pesaran et al (2001). This is most flexible approach because it deals with both type of integrating orders. This approach is most significant than other approaches because it is more robust (appropriate) for small samples. (Ghatak \& Siddiki 2001). We can't use ARDL on integrating of order two I (2). The long run ARDL equations for both models are as below:

$$
C H L_{t}=\alpha_{1}+\sum_{i=1}^{p} \beta_{i} C H L_{t-i}+\sum_{i=0}^{q} \gamma_{i} P O P_{t-i}+\sum_{i=0}^{r} \delta_{i} G D P C_{t-i}+\mu_{t}
$$


$C H L_{t}=\alpha_{1}+\sum_{i=1}^{p} \beta_{i} C H L_{t-i}+\sum_{i=0}^{q} \gamma_{i} G A_{t-i}+\sum_{i=0}^{r} \delta_{i} G I_{t-i}+\sum_{i=0}^{s} \varepsilon_{i} F D I_{t-i}+\sum_{i=0}^{t} \zeta_{i} G S_{t-i}+$ $\sum_{i=0}^{u} \eta_{i} G I_{t-i}+\sum_{i=0}^{w} \theta_{i} P O P U_{t-i} \sum_{i=0}^{W} l_{i} P O P R_{t-i}+\sum_{i=0}^{x} \kappa_{i} T O_{t-i}+\mu_{t}$

Error correction model is used to check the short run relationship. An error-correction model is a dynamic model in which "the movement of the variables in any periods is related to the previous period's gap from long-run equilibrium."

The ECM of the two models are

$$
\begin{aligned}
& \triangle C H L_{t}=\gamma_{0}+\sum_{i=1}^{p} \beta_{i} \triangle C H L_{t-i}+\sum_{i=0}^{q} \gamma_{i} \Delta P O P_{t-i}+\sum_{i=0}^{r} \delta_{i} \Delta G D P C_{t-i}+\lambda_{1} C H L_{(t-1)}+ \\
& \lambda_{2} P O P_{(t-1)}+\lambda_{3} G D P C_{(t-1)}+\mu_{t}
\end{aligned}
$$

$$
\begin{aligned}
& \Delta L C H L_{t}=\omega_{1}+\sum_{i=1}^{p} \beta_{i} L C H L_{t-i}+\sum_{i=0}^{q} \gamma_{i} \Delta L A G_{t-i}+\sum_{i=0}^{r} \delta_{i} \Delta L I G_{t-i}+\sum_{i=0}^{s} \varepsilon_{i} \Delta L S G_{t-i}+ \\
& \sum_{i=0}^{t} \zeta_{i} \Delta L F D I_{t-i}+\sum_{i=0}^{u} \eta_{i} \Delta L P O P R_{t-i}+\sum_{i=0}^{v} \theta_{i} \Delta L P O P U_{t-i} \sum_{i=0}^{w} l_{i} \Delta L T O_{t-i}+\lambda_{1} L C H L_{(t-1)}+ \\
& \lambda_{2} L A G_{(t-1)}+\lambda_{3} L I G_{(t-1)}+\lambda_{4} L S G_{(t-1)}+\lambda_{5} L F D I_{(t-1)}+\lambda_{6} L P O P R_{(t-1)}+\lambda_{7} L P O P U_{(t-1)}+ \\
& \lambda_{8} L T O_{(t-1)}+\mu_{t}+\mu_{t}
\end{aligned}
$$

\section{Empirical Findings}

ADF test is applied the results in table:4.1 are drawn on the based on SBC to draw inferences about the order of integration.

Table 4.1 : unit root

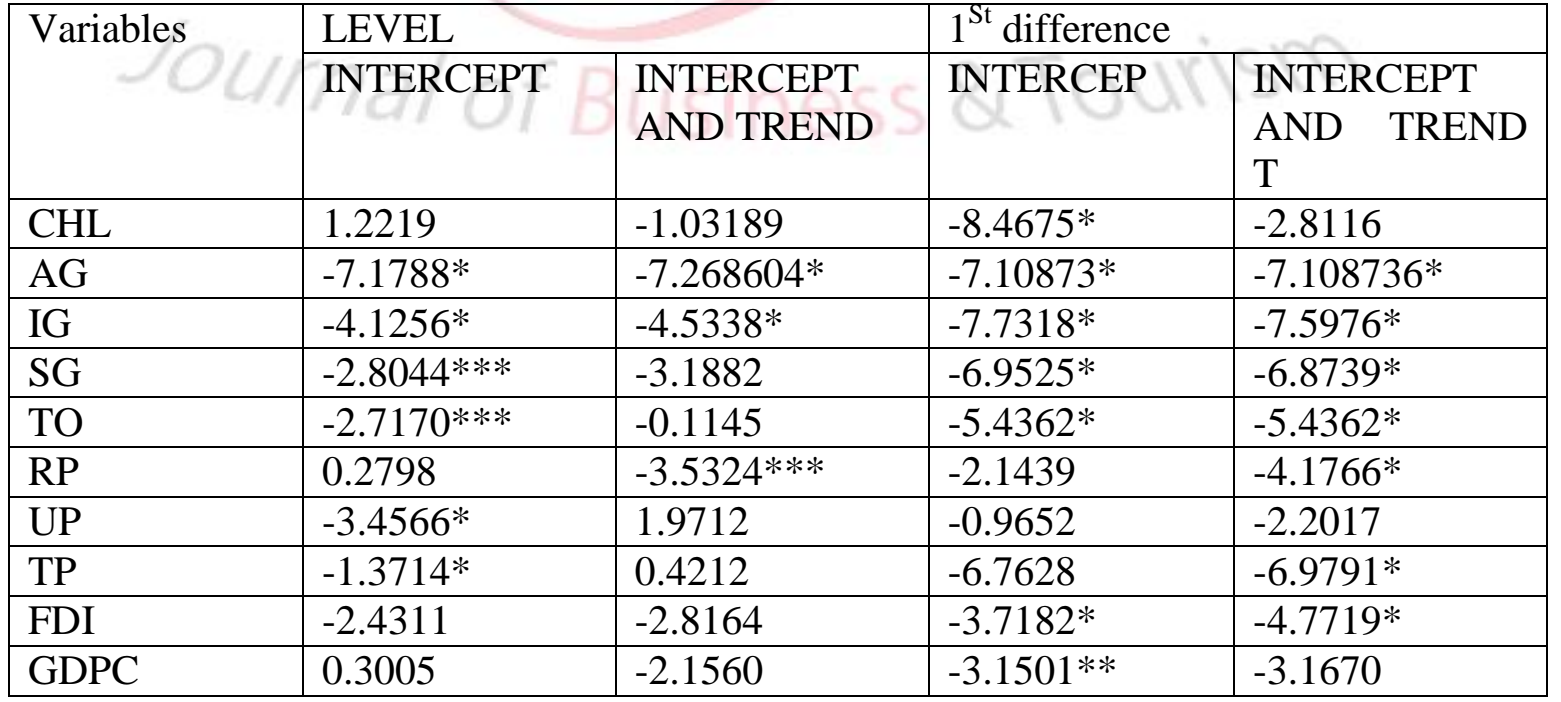

$*, * *, * * *$ shows series stationary at $1 \%, 5 \%$, and $10 \%$.

All the variables are stationary on level except GDPC and FDI. The order of integration is mixed. The null hypothesis of unit root is failed to accept at level. So we have the 
choice to apply ARDL. In this study the long run and short dynamics are required. To achieve the objective ARDL is useful technique.

First the overall effect of gdp growth and population growth is tested on the child labor by using the following model:

$(\mathrm{CL})=\mathrm{b} 0+\mathrm{b} 1(\mathrm{Gdp})+\mathrm{b} 2(\mathrm{POP})$

The long run and short run dynamics are identified by using ARDL Pesaran and shin (1999) mechanism. At first step lag order is selected through bound test approach. cointegration exist at third lag the value of $F$ statistics $F(3,17)=4.3444[.019]$ lies above the following bound3.182 to 4.126 at $90 \%$ level with intercept and no trend. The diagnostic test is applied to identify that there is no problem of heteroscedasticity and autocorrelation in table: 4.2. The LM test and F-TEST identify the model is homoscedastic and there is no autocorrelation and functional form is apt. the p-values in parentheses are greater than ten percent which clearly indicates the normality

Table 4.2: Diagnostic Test

\begin{tabular}{|c|c|c|}
\hline Test Statistics & LM Version & F Version \\
\hline Serial Correlation & CHSQ $(1)=2.1391[.144]$ & $\mathrm{F}(1,26)=1.9271[.177]$ \\
\hline Functional Form & CHSQ $(1)=1.0190[.313]$ & $\mathrm{F}(1,26)=.84387[.367]$ \\
\hline Normality & CHSQ $(2)=2.2287[.328]$ & Not applicable \\
\hline Heteroscedasticity & $\begin{array}{l}\text { CHSQ( } \\
.040717[.840]\end{array}$ & $\mathrm{F}(1,29)=.038054[.847]$ \\
\hline
\end{tabular}

The long run dynamics in table :4.3 are found on the second lag based on SBC. The long run results revealed that the coefficient of total population (TP) has negative impact on child labor, as the TP growth increases by one unit it decreases the child labor growth by $1.74 \%$ and has significant impact at $1 \%$ level. The GDPC is significant at $10 \%$ level it point out that as percapita growth increases it reduces child labor by $0.007 \%$ as in Edmonds (2004,2005),Samy(2007)and Basu (1998). It indicates that when percapita income increased it increased the purchasing power of the households. Households spend their income on the education of their children that reduced the child labor

Table 4.3: ARDL Long Run Estimates

\begin{tabular}{|l|l|l|l|}
\hline VARIABLES & COEFFICIENT & $\begin{array}{l}\text { STANDARD } \\
\text { ERROR }\end{array}$ & $\begin{array}{l}\text { T-RATIO(P- } \\
\text { VALUES })\end{array}$ \\
\hline TP & -1.7431 & 0.61685 & $-2.8257 *(0.009)$ \\
\hline GDPC & -0.0073 & 0.0036 & $-2.0204 * * *(0.054)$ \\
\hline $\mathrm{C}$ & 8.5543 & 3.7171 & $2.3013^{* *[.030]}$ \\
\hline
\end{tabular}

$*, * *, * * *$ identifies the t-ratio is significant at $1 \%, 5 \%, 10 \%$.

The short run dynamics in table:4.4 depicted that total population growth increased child labor by $3.39 \%$ insignificantly. Population growth takes place than more mouth demand more foods so people send their children to work. The gdp percapita growth decreased child labor by $0.01 \%$ at five percent level of significance. 
Table 4.4: Short Run ECM

\begin{tabular}{|l|l|l|l|}
\hline REGRESSORS & COEFFICIENT & $\begin{array}{l}\text { STANDARD } \\
\text { ERROR }\end{array}$ & $\begin{array}{l}\text { T-RATIO(P- } \\
\text { VALUES) }\end{array}$ \\
\hline DTP & 3.3963 & 2.9894 & $1.0692[.295]$ \\
\hline Dgdpc & -.01165 & .0058 & $-1.985[.058]$ \\
\hline Dc & 13.5889 & 6.0339 & $2.252^{* *[.058]}$ \\
\hline Ecm(-1) & -1.5885 & .1588 & $-9.9981[.000]$ \\
\hline R-Squared & .8003 & R-Bar-Squared & .7684 \\
\hline F-stat & $33.4045[.000]$ & Durbin's h-statistic & $-1.7594[.079]$ \\
\hline
\end{tabular}

$*, * *, * * *$ identifies the t-ratio is significant at $1 \%, 5 \%, 10 \%$.

The value of ecm is -1.58 which depict that economy converge towards equilibrium before the one year at the speed of $144 \%$. The R-Square showed $77 \%$ variation in child labor due to TPG and GDPC. The range of Durbin- h-statistics $-1.96<\mathrm{DH}<1.96$ which indicates

The second model capture the effect of different sector growth rate on the child labor. The log log model is used to infer percentage changes.

$\mathrm{LCL}=\mathrm{a}+\mathrm{b}(\mathrm{LAG})+\mathrm{b} 2(\mathrm{LIG})+\mathrm{b} 3(\mathrm{LSG})+\mathrm{b} 4(\mathrm{LFDI})+\mathrm{b} 5(\mathrm{LTO})+\mathrm{b} 6(\mathrm{LPOPR})+$ b7(LPOPU)

In this model growth of each sector i.e; agriculture, industry, and services are tested. The globalization impact is check through foreign direct investment and trade openness. The mix order of integration implies that ARDL is appropriate technique for analyzing the long run and short run dynamics. At foremost stage the lag order is selected through bound testing process. The value of F-statistics 5.7863[.011]make clear that the cointegration exist at second lag. The value lies above the range 3.027 to 4.296 with intercept and no trend at $99 \%$ level.

The diagnostic test in table: 4.5 validate that there is no prevalence autocorrelation, serial correlation and functional form is correct and the distribution is normal. The p-values in the LM and F version tests in parenthesis greater than ten percent which be evident the fact.

Table 4.5: Diagnostic Test

\begin{tabular}{|l|c|l|}
\hline Test Statistics & LM Version & F Version \\
\hline Serial Correlation & $3.7213[.154]$ & $1.8409[.198]$ \\
\hline Functional Form & $1.2615[.261]$ & $0.5706[.463]$ \\
\hline Normality & $1.1816[.554]$ & Not applicable \\
\hline Heteroscedasticity & $0.0475[.827]$ & $0.0444[.835]$ \\
\hline
\end{tabular}

The long run dynamics are found on the second lag based on SBC at ARDL $(1,2,2,1,1,0,0,1)$ in table:4.6. The agriculture growth increase by one percent it decreases the child labor by 0.05 percent at $10 \%$ level of significance. The new 
technology and innovations in the agriculture sector lessen the role of unskilled worker like children. As industrial sector grows it decreases child labor by 0.257 percent and significant at 5\% level of significance. Services sector growth has significant role which decreases the child labor by $0.09 \%$ at ten percent level. Services sector growth basically indicates that education level increases the number of persons engage in services sector and prefer their children to get into education. In 1950 the Pakistan literacy rate was 14\% and in 2012 it was 58\% (UNESCO). The rural population growth increases the child labor by $3.65 \%$ at one percent level of significance. The urban population growth decreased the child labor by $12.7 \%$ at one percent level of significance.

Table 4.6: ARDL Long Run Estimates

\begin{tabular}{|l|l|l|l|}
\hline VARIABLES & COEFFICIENT & $\begin{array}{l}\text { STANDARD } \\
\text { ERROR }\end{array}$ & $\begin{array}{l}\text { T-RATIO(P- } \\
\text { VALUES) }\end{array}$ \\
\hline AG & -.0568 & .03116 & $-1.8253^{* * *[.089]}$ \\
\hline IG & -.2577 & .07139 & $-3.6102 * *[.003]$ \\
\hline SG & -.0901 & 0.066 & $-1.3651[.194]$ \\
\hline UPG & -12.760 & 2.6272 & $-4.8570 *[.000]$ \\
\hline RPG & 3.6552 & .7463 & $4.8973 *[.000]$ \\
\hline FDI & -.4423 & .1186 & $-3.7308^{* *}[.002]$ \\
\hline TO & 6.3863 & 1.4254 & $4.4802 *[.001]$ \\
\hline C & 30.3188 & 6.6583 & $4.5536^{*}[.000]$ \\
\hline R-Squared & .85369 & R-Bar-Squared & .69693 \\
\hline F-stat & $5.4458[.001]$ & & \\
\hline
\end{tabular}

$*, * *, * * *$ identifies the $\mathrm{t}$-ratio is significant at $1 \%, 5 \%, 10 \%$.

The trade openness and FDI capture the worth of globalization on child labor. The FDI reduced the child labor growth by 0.44 at $5 \%$ level of significance Escobal(2007),Neumayer and de Soysa (2005a, 2007). Trade openness played insignificant role in declining the child labor growth this is because the other sectors which are not engaged in trade absorb all the child labor as in Bandyopadhyay(2005) which is against Edmonds(2004) and Gupta(2005).

The short run ARDL(1,0,1,1,0,0,0,1,0) results selected based on Schwarz Bayesian Criterion of ecm in table:4.7 revealed that all sectors growth has negative and significant impact on child labor growth rate but servicessector has found statistically insignificant and positive impact on child labor growth in short run. In the short run all sectors are expanding they need time to build infrastructure and hire skilled worker that's the reason services sector growth plays insignificant role in decreasing the child labor in short run. The urban population growth decrease the child labor and rural population growth as well the coefficients are statistically significant at 5\% and $1 \%$ level of significance as indicated by Khalid and Shahnaz(2004). The FDI significantly decreased the child labor by 0.34 percent as in Kis-Katos(2011) and $\operatorname{Voy}(2014)$ but trade openness has 
insignificant role in decreasing the child labor growth the reason is that Pakistan is a developing economy and in such types of economies trade policies required long time for implementation as point out by Edmonds(2005a, 2005b, 2006) and Flanagan (2006) .

The error correction mechanism revealed that the economy converges towards equilibrium before completion of one year at the speed of $1.88 \%$. The R-square explain 94\% variation in dependent variable due to all regressors. The Durbin h-statistics which is -0.1887 the autocorrelation not exist in the data. The model is good fit because Fstatistic is statistically significant.

Table 4.7: Short Run ECM

\begin{tabular}{|l|l|l|l|}
\hline REGRESSORS & COEFFICIENT & $\begin{array}{l}\text { STANDARD } \\
\text { ERROR }\end{array}$ & $\begin{array}{l}\text { T-RATIO(P- } \\
\text { VALUES) }\end{array}$ \\
\hline dAG & -.045929 & .031647 & $-1.4513[.163]$ \\
\hline dIG & -.25083 & .059363 & $-4.2253[.000]$ \\
\hline dSG & -.16329 & .12215 & $-1.3368[.197]$ \\
\hline dUPG & -46.5414 & 12.7474 & $-3.6511^{*}[.003]$ \\
\hline dRPG & -92.1017 & 17.7502 & $-5.1888^{*}[.000]$ \\
\hline dFDI & -0.7279 & 0.2568 & $-2.8338^{*}[.013]$ \\
\hline dTO & 11.5710 & 2.6796 & $4.3181[.000]$ \\
\hline dC & 54.933 & 12.5788 & $4.3671[.001]$ \\
\hline Ecm(-1) & -1.881 & 0.1258 & $-14.4032[.000]$ \\
\hline R-Squared & 0.9482 & R-Bar-Squared & 0.8927 \\
\hline F-stat & $25.6348[.000]$ & Durbin's h-statistic & $-.1887[.059]$ \\
& & & \\
\hline
\end{tabular}

$*, * *, * * *$ identifies the t-ratio is significant at $1 \%, 5 \%, 10 \%$

Cusum and cusumsq test for parameter stability in figure:4.1 and figure:4.2 depict that the model is stable. The line of cusum and cusumsq fluctuate between the upper and lower bound of critical F-statistics and does not cross it.

Figure 4.1: Cumulative Sum of Recursive Residuals

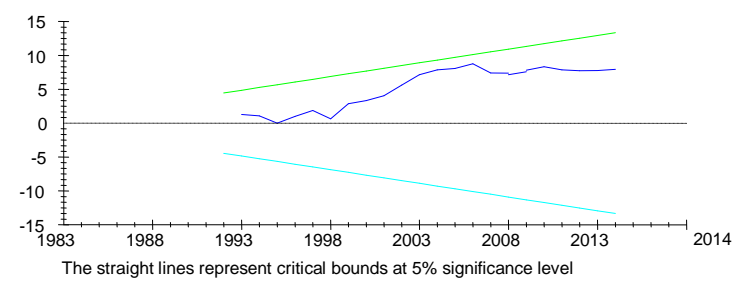

Figure 4.2: Plot of Cumulative Sum of Squares of Recursive Residuals 


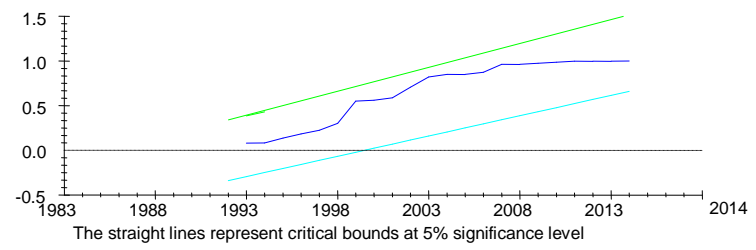

\section{Conclusion and Policy Suggestions}

Child labor is the issue of developing economies and Pakistan is the major victim of it. The study formulated two models for analyzing this issue in Pakistan. First model of child labor revealed that with growth in GDP per capita and total population child labor was significantly decreased in the long run but in the short run GDPC decreased the child labor and population growth had insignificant effect. In the second form agriculture industrial services sector growth significantly decreased the child labor growth except manufacturing sector growth in the long run. Trade openness did not reduce the child labor significantly where as FDI did reduce it. Urban population growth significantly decreased the child labor whereas rural population growth did not. The short run analysis depicted that all sectors growth decreased the child labor significantly except the manufacturing, it has insignificant role in reduction of child labor growth.

Child labor cannot be reduced overnight. On the basis of estimated results study suggests the Government must focus on the good literacy promoting schemes. Adult literacy programs should be initiated to provide the skill workers in the economy so that they got appropriate wage rate and not engage their children in the work. The trade policy and ILO rules should be implemented; this will help in reducing child labor and improving the trade balance of the country. For the attainment of reduction in child labor national policies are implemented in align with the trade policies. The aid from developed countries should be properly utilized that the benefits attained by the lay man so that they do not indulge their children in work.

\section{References}

Ahmed, A., \& Ahsan, H. (2011). Contribution of services sector in the economy of Pakistan. Working Papers \& Research Reports, 2011.

Baradaran, S., \& Barclay, S. H. (2011). Fair Trade and Child Labor. Columbia Human Rights Law Review, 43(1).

Basu, K. and P. H. Van (1998). "The economics of child labor." American Economic Review 88(3): 412-427.

Bandyopadhyay, Subhayu \& Bandyopadhyay, Sudeshna C., 2005. "Trade and Child Labor: A General Equilibrium Analysis," IZA Discussion Papers 1514, Institute for the Study of Labor (IZA).

Brown, D.K., Deardorff, A.V. and R.M. Stern, (2002), "The determinant of Child Labor :Theory and evidence",RSIE Discussion Paper, 486. 
Edmonds, E. V., \& Pavcnik, N. (2004). DP4309 International Trade and Child Labour: CrossCountry Evidence.

Edmonds, E.V. and Pavcnik,N. (2005). The effect of trade liberalization on child labor, Journal of International Economics, 65, (2), 401-419

Edmonds, E.V and Pavcnik,N. (2006), International trade and child labor: Cross-country evidence, Journal of International Economics, 68, (1), 115-140.

Escobal, J. (2007). Trade Liberalization and Children: Understanding and Coping with Children's Vulnerabilities. 2020 .Focus Brief on the World's Poor and Hungry People. Washington, DC: IFPRI.

ECONOMICS OF CHILD LABOUR (2013). Doctor of Philosophy, University of Nottingham.

Flanagan, R. J. (2006). Globalization and labor conditions : working conditions and worker rights in a global economy. Oxford ; New York, Oxford University Press.

Kis-Katos, K. \& Sparrow, R.(2011). Child Labor and Trade Liberalization in Indonesia, Journal of Human Resources, 46 (4): $722-749$ (also as IZA Discussion Paper No. 4376, IZA(2009) Bonn).

Khalid, U. \& Shahnaz L.(2004). Socio Economic Conditions of Child Labourers in Pakistan: Evidence from the Labour Force Survey. Lahore Journal of Economics, 9(1), 86.

Mohammad Mafizur Rahman, Rasheda Khanam, (2012) "Child Labour: The Effects of Globalisation," Journal Of Applied Business And Economics. 13 (4). 59-71.

Siddiqi, F., and H. Patrinos. 1995. Child labor: Issues, causes and interventions .Human Resources and Operations Policy Working Paper 56. Washington, D.C.: World Bank.

Samy.Y, and Dehejia.V, H.,(2007). Trade and Labor Standards: A Reviewofthe Theory and NewEmpirical Evidence. No 07-12, Carleton Economic Papers, Carleton University, Department of Economics.

Sarbajit Chaudhuri \& Manash Ranjan Gupta, 2005. "Child Labour And Trade Liberalization In A Developing Economy," Labor and Demography 0510017, EconWPA.

Voy .A (2014) Sector- specific variation in the effect of trade on child labor .Economics Bulletin, Vol. 34 No. 1 pp. 385-394.

Nawaz, M; Nasir, M; Ali, A and Chaudhry W. (2011). Trade Liberalization and Child Labor: A Case Study of Pakistan, Transition Studies Review, 18, (2), 361-376.

Neumayer, E, \&De Soysa ,I. (2005a). "Globalization and the Right to Free Association and Collective Bargaining: An Empirical Analysis,” World Development 34 (1), pp. 31-49.

Neumayer, E., \& De Soysa, I. (2007). Globalisation, women's economic rights and forced labour. The World Economy, 30(10), 1510-1535.

Katie, $\mathrm{H}$ (2013). The 10 worst countries for child labor. CNN 15 Oct.http://edition.cnn.com/2013/10/15/world/child-labor-index-2014/

Philippines struggling to tackle child prostitution.Date 10.03.2015 Author Roxana Isabel Duerr / sh http://www.dw.de/philippines-struggling-to-tackle-child-prostitution/a-18305386 
Child labour in India is addressed by the Child Labour Act, 1986 and National Child Labour Project. http://www.childlineindia.org.in/child-labour-india.htm

India Today Online New Delhi, November 25, 2013 | UPDATED 15:49 IST .Child prostitution in India: Awareness can help! http://indiatoday.intoday.in/education/story/childprostitution-in-india-awareness-can-help/1/326450.html

Gathia, J. A. (1999). Child prostitution in India. Concept Publishing Company

Wessells, M. G. (2006). Child soldiers: From violence to protection. Harvard University Press. https://www.questia.com/library/psychology/relationships-and-the-family/children/childsoldiers

Hartjen, C. A., \& Priyadarsini, S. (2012). The global victimization of children: Problems and solutions. Springer Science \& Business Media.

Finnstrom, S. (2008). Child Soldiers in Africa by Alcinda Honwana Philadelphia, PA: University of Pennsylvania Press, 2006. Pp. 202,£ 29.50;£ 15.00 (pbk.). The Journal of Modern African Studies, 46(01), 161-162.

UNICEF (1997) Report on The State of The World's Children

World Bank(2014):, World Development Indicators CD-ROM

Pakistan Economic Survey, Various issues, The Finance Division, Ministry of Finance, Pakistan 